Article

\title{
Synthesis of Copper Oxide-Based Nanoformulations of Etoricoxib and Montelukast and Their Evaluation through Analgesic, Anti-Inflammatory, Anti-Pyretic, and Acute Toxicity Activities
}

\author{
Sulaiman Sulaiman ${ }^{1,2}$, Shabir Ahmad ${ }^{1}$, Syeda Sohaila $\mathrm{Naz}^{2}$, Sara Qaisar ${ }^{2}$, Sayyar Muhammad ${ }^{1}$, \\ Amal Alotaibi ${ }^{3}$ (D) and Riaz Ullah $4, *$ (D)
}

Citation: Sulaiman, S.; Ahmad, S.; Naz, S.S.; Qaisar, S.; Muhammad, S.; Alotaibi, A.; Ullah, R. Synthesis of Copper Oxide-Based

Nanoformulations of Etoricoxib and Montelukast and Their Evaluation through Analgesic,

Anti-Inflammatory, Anti-Pyretic, and Acute Toxicity Activities. Molecules 2022, 27, 1433. https://doi.org/ $10.3390 /$ molecules 27041433

Academic Editor: Josef Jampilek

Received: 8 February 2022

Accepted: 14 February 2022

Published: 21 February 2022

Publisher's Note: MDPI stays neutral with regard to jurisdictional claims in published maps and institutional affiliations.

Copyright: (C) 2022 by the authors. Licensee MDPI, Basel, Switzerland. This article is an open access article distributed under the terms and conditions of the Creative Commons Attribution (CC BY) license (https:// creativecommons.org/licenses/by/ $4.0 /)$.
1 Department of Chemistry, Islamia College University, Peshawar 25120, Khyber Pakhtunkhwa, Pakistan; sulmankkpp@gmail.com (S.S.); shabir.ahmad@icp.edu.pk (S.A.); sayyar@icp.edu.pk (S.M.)

2 Nanosciences and Technology Department, National Centre for Physics, Quaid-i-Azam University Campus, Islamabad 44000, Punjab, Pakistan; syedasohailanaz@yahoo.com (S.S.N.); sara.qaisar@ncp.edu.pk (S.Q.)

3 Department of Basic Science, College of Medicine, Princess Nourah Bint Abdulrahman University, P.O. Box 84428, Riyadh 11671, Saudi Arabia; amaalotaibi@pnu.edu.sa

4 Department of Pharmacognosy (MAPPRC), College of Pharmacy, King Saud University, Riyadh 11451, Saudi Arabia

* Correspondence: rullah@ksu.edu.sa

\begin{abstract}
Copper oxide nanoparticles (CuO NPs) were synthesized through the coprecipitation method and used as nanocarriers for etoricoxib (selective COX-2 inhibitor drug) and montelukast (leukotriene product inhibitor drug) in combination therapy. The CuO NPs, free drugs, and nanoformulations were investigated through UV/Vis spectroscopy, FTIR spectroscopy, XRD, SEM, and DLS. SEM imaging showed agglomerated nanorods of $\mathrm{CuO}$ NPs of about $87 \mathrm{~nm}$ size. The CE1, CE2, and CE6 nanoformulations were investigated through DLS, and their particle sizes were 271, 258, and $254 \mathrm{~nm}$, respectively. The nanoformulations were evaluated through in vitro anti-inflammatory activity, in vivo anti-inflammatory activity, in vivo analgesic activity, in vivo anti-pyretic activity, and in vivo acute toxicity activity. In vivo activities were performed on albino mice. BSA denaturation was highly inhibited by CE1, CE2, and CE6 as compared to other nanoformulations in the in vitro anti-inflammatory activity. The in vivo bioactivities showed that low doses $(5 \mathrm{mg} / \mathrm{kg})$ of nanoformulations were more potent than high doses (10 and $20 \mathrm{mg} / \mathrm{kg}$ ) of free drugs in the inhibition of pain, fever, and inflammation. Lastly, CE2 was more potent than that of other nanoformulations.
\end{abstract}

Keywords: etoricoxib; montelukast; $\mathrm{CuO}$ nanoparticles; nanomedicine; analgesic potential; antipyretic agent; anti-inflammatory agent

\section{Introduction}

Nanotechnology is a field of research in which substances with one dimension less than $100 \mathrm{~nm}$ are studied [1]. The origin of nanotechnology can be traced back to the famous lecture of Nobel laureate Richard P. Feynman (1959) in which he stated that "There's Plenty of Room at the Bottom" [2,3]. Nanotechnology has brought revolutionary changes in the field of science, technology, agriculture, energy, health, and other industrializations. These changes are related to the vast behaviors of nanoparticles [4]. Copper oxide nanoparticles (CuO NPs) have a large surface area and unique morphological structures which impart them with characteristic physical and chemical properties. They are widely applicable in nanomedicines [5], PN junction diodes [6], humidity sensing [7], lithium-ion batteries [8], organic synthesis [9], antimicrobial activity, and biomedicine. CuO NPs show anti-bacterial and other anti-microbial activities [10]. 
Non-steroidal anti-inflammatory drugs (NSAIDs) are the most widely prescribed drugs for the treatment of pain, fever, and inflammation worldwide [11]. Acetylsalicylic acid was the first NSAID that was synthesized by Felix Hoffman in 1897 [12]. In 2004, more than 111 million NSAIDs were prescribed in the USA. Moreover, the number of prescriptions of NSAIDs in Europe is 7.7\% [13]. These drugs are mostly prescribed to patients at or above the age of 65 years. These drugs are effective for pain, fever, and inflammation in osteoarthritis, psoriatic arthritis, injury, gout, and rheumatoid arthritis [14].

The primary cause of pain, fever, and inflammation is the production of the cyclooxygenase (COX) enzyme in the body of various organisms [15]. The basic function of NSAIDs is to stop the production of COX. The blockage of COX leads to the inhibition of the conversion of arachidonic acid to prostacyclin which is the cause of pain, fever, and inflammation in the body [16-18]. Although NSAIDs are effective against several diseases, they may also lead to some side effects such as gastrointestinal bleeding, renal failure, and heart diseases. The cause of inflammation and pain is from COX-2 enzymes and leukotriene products but most NSAIDs block both COX-1 and COX-2 enzymes [19]. However, COX-1 is important (via thromboxane) for the protection of the stomach [20]. The inhibition of COX-1 enzymes leads to gastric and heart problems [20,21]. Although some selective COX-2 inhibitors are available on the market, their high doses and bulk form lead to severe side effects [22,23]. The potency of drugs is enhanced with targeted drug delivery tools such as soft materials involved in biological and artificial membranes [24], PEG [25], alginate, and chitosan-coated nanoparticles [26]. These tools also reduce drug side effects.

In this research, efforts were made to synthesize nanoformulations of selective inhibition of COX-2 and leukotriene products. Therefore, etoricoxib (ET) was selected as a COX-2 inhibitor, which is mostly prescribed for the treatment of pain and arthritic conditions such as rheumatoid arthritis and osteoarthritis [27], and montelukast (MT) was used as a leukotriene product inhibitor drug. $\mathrm{CuO}$ NPs were used as nanocarriers for ET and MT in combination therapy. CuO NPs also possess potency as antioxidant and anticancer agents [28]. They show antibacterial activity against both Gram-positive and Gram-negative bacteria [29]. The nanosize of copper oxide provides a large surface area for the interaction of drugs and enhances its potency. Low doses of nanodrugs are more potent due to their large surface area and small size than bulk drugs. Nanoparticle-mediated drug delivery enhances the potency, solubility, and bioavailability of drugs [30,31], while free drugs are less soluble and have low bioavailability [32], and their high dose is administrated which increases the risk of side effects [33]. In this combination therapy, two drugs were loaded onto $\mathrm{CuO}$ NPs for the treatment of inflammation, fever, and pain. CuO NPs are disinfectant [34], antifouling [35], antiviral [36], and antimicrobial agents [37]; therefore, they were selected as nanocarriers for ET and MT to inhibit COX-2 and leukotriene products.

\section{Results and Discussions}

\subsection{Structural Analysis}

2.1.1. UV/Vis Spectroscopy

UV/Vis spectroscopy was used for the analysis of copper oxide nanoparticles, drugs, and synthesized nanomaterials (Figure 1). UV/Vis spectroscopy is a significant tool that is used to investigate the nature of bonds, bandgap calculations, and surface plasmon resonances. The UV/Vis spectrum was performed in the range of $200-800 \mathrm{~nm}$. Solutions of $\mathrm{CuO} \mathrm{NP}, \mathrm{ET}, \mathrm{MT}$, and synthesized nanomaterials were prepared in ethanol. A characteristic peak of $\mathrm{CuO}$ NPs was observed at $290 \mathrm{~nm}$, which confirmed its synthesis [38,39]. A characteristic peak of ET was observed at $233 \mathrm{~nm}$ which corresponds to the literature [40]; while that of MT was observed at 284, 324, 343, and $360 \mathrm{~nm}$ [41]. The characteristic peak of copper oxide nanoparticles disappeared in the nanoformulation, which indicates the adsorption of drugs. The peak of that drug was more prominent in nanoformulations where its ratio was higher. The peaks of MT were prominent in CE5, CE6, and CE7; while those of ET were prominent in CE1, CE2, and CE3. 


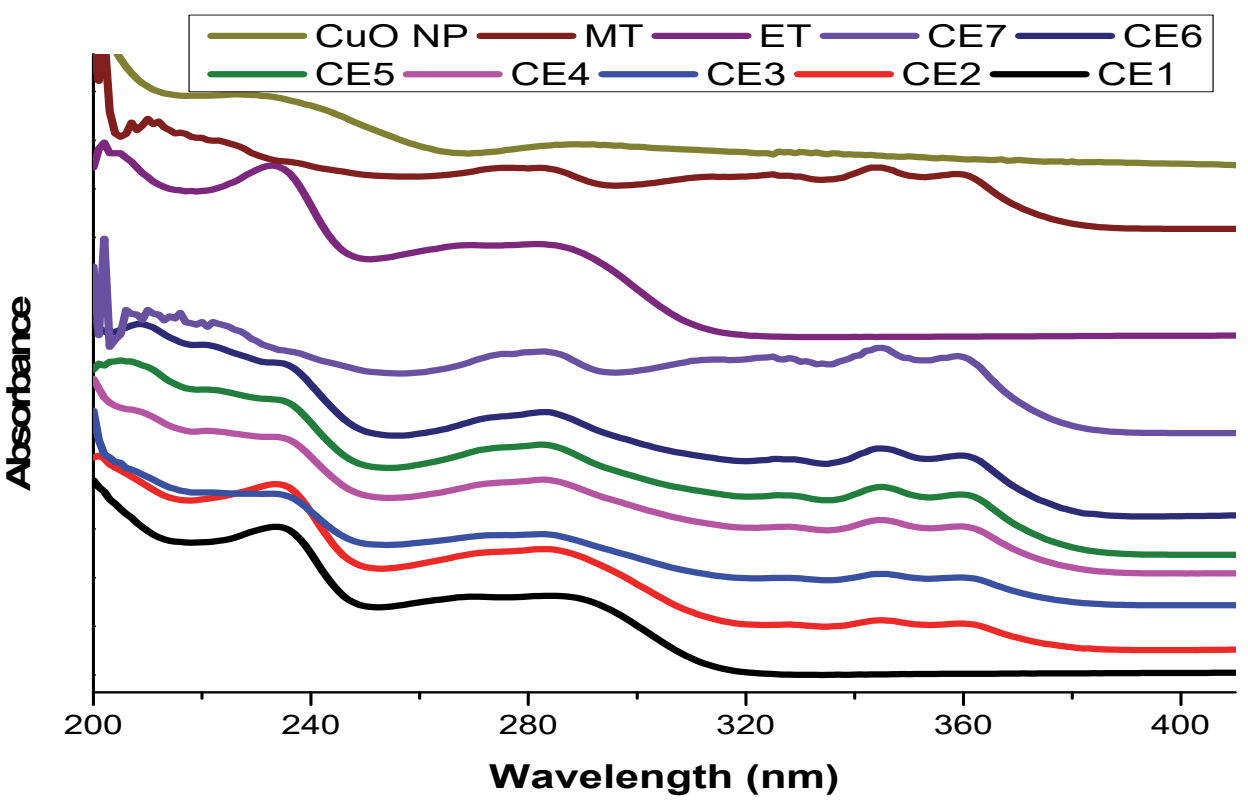

Figure 1. UV/vis spectrum of copper oxide nanoparticles (CuO NPs), etoricoxib (ET), montelukast (MT), and synthesized nanomaterials.

\subsubsection{FTIR Spectroscopy}

The synthesis of $\mathrm{CuO}$ NPs was also confirmed from FTIR analysis (Figure 2). The synthesis of $\mathrm{CuO}$ NPs was confirmed by the appearance of the characteristic peaks of $\mathrm{CuO}$ NPs in specific regions. The vibrational mode of $\mathrm{CuO}$ NPs was revealed in the range of $500-700 \mathrm{~cm}^{-1}$ by the three absorption peaks. The stretching of $\mathrm{Cu}-\mathrm{O}$ was indicated by the peak at $525 \mathrm{~cm}^{-1}$. The synthesis of $\mathrm{CuO}$ NPs was confirmed from the peaks at $525 \mathrm{~cm}^{-1}$ and $602 \mathrm{~cm}^{-1}[42,43]$. Characteristic peaks of ET were observed at 772, 830, 1010, $1140 \mathrm{~cm}^{-1}$ (corresponding to sulphone groups $(-\mathrm{S}=\mathrm{O})$ ) [44], $1598.9 \mathrm{~cm}^{-1}(\mathrm{C}=\mathrm{N}$ stretching vibration), 839.0, 781.1, and $638.0 \mathrm{~cm}^{-1}$ (C-Cl stretching vibration) [45-47]. The characteristic peaks of MT were observed at 3396 (COOH stretching), 2980 (aromatic C-H stretching), 2925 (aliphatic C-H stretching), 1610 (CC stretching), 1595 (CN stretching), 1497 (aliphatic $\mathrm{C}-\mathrm{H}$ bending), 1132 (C-O stretching), 1068 (aromatic $\mathrm{C}-\mathrm{Cl}$ stretching), 837 (aromatic C-H bending), and 697 (C-S stretching) [48]. Although a few of the ET and MT peaks disappeared in nanoformulations, most of them appeared which shows their adsorption onto $\mathrm{CuO}$ NPs.

\subsubsection{X-ray Diffractometry}

The synthesis of CuO NPs was confirmed from UV/vis spectroscopy and FTIR spectroscopy, but it was further matched with JCPDS cards for XRD analysis. X-ray diffractometry (XRD) (Figure 3) was conducted by using a D8 advance Bruker X-ray diffractometer (Bruker Germany) at NCP Islamabad, Pakistan. Characteristic peaks of $\mathrm{CuO}$ NPs were observed at $2 \theta=32.44^{\circ}, 35.47^{\circ}, 38.62^{\circ}, 48.86^{\circ}, 53.45^{\circ}, 58.06^{\circ}, 61.60^{\circ}, 66.45^{\circ}$, and $68.17^{\circ}$ in the XRD spectrum which corresponded to 110, 002, 111, 112, 020, 202,113, 311, and 220 planes of the Miller's indices, respectively [49]. The highly crystalline nature of the synthesized $\mathrm{CuO}$ NPs was confirmed from the sharp and well-defined reflections of the $\mathrm{CuO}$ NPs (JCPDS card no. 01-080-0076) [50]. CuO NPs have a monoclinic structure with a crystallite size of $13.7 \mathrm{~nm}$. Characteristic peaks of ET were observed at $2 \theta=11.9,13.3$, 16.5, 16.6, 18.2, 20.2, 22.8, 24.2, 26.5, 28.7, 29.4, 30.3, 32.5, 32.9, 34.8, 36.1, 39.1, 40.1, 41.2, $42,42.9,45.7,47.6,49.3$, and 53.2 [51]. These peaks were masked or disappeared in the nanoformulations. The disappearance of peaks in the nanoformulations shows that ET was attached or converted to an amorphous form. MT has no characteristic peak in the XRD spectrum due to its amorphous nature. The crystallite structure of CuO NPs, ET, and nanoformulations was calculated through the Scherrer formula (Table 1). 


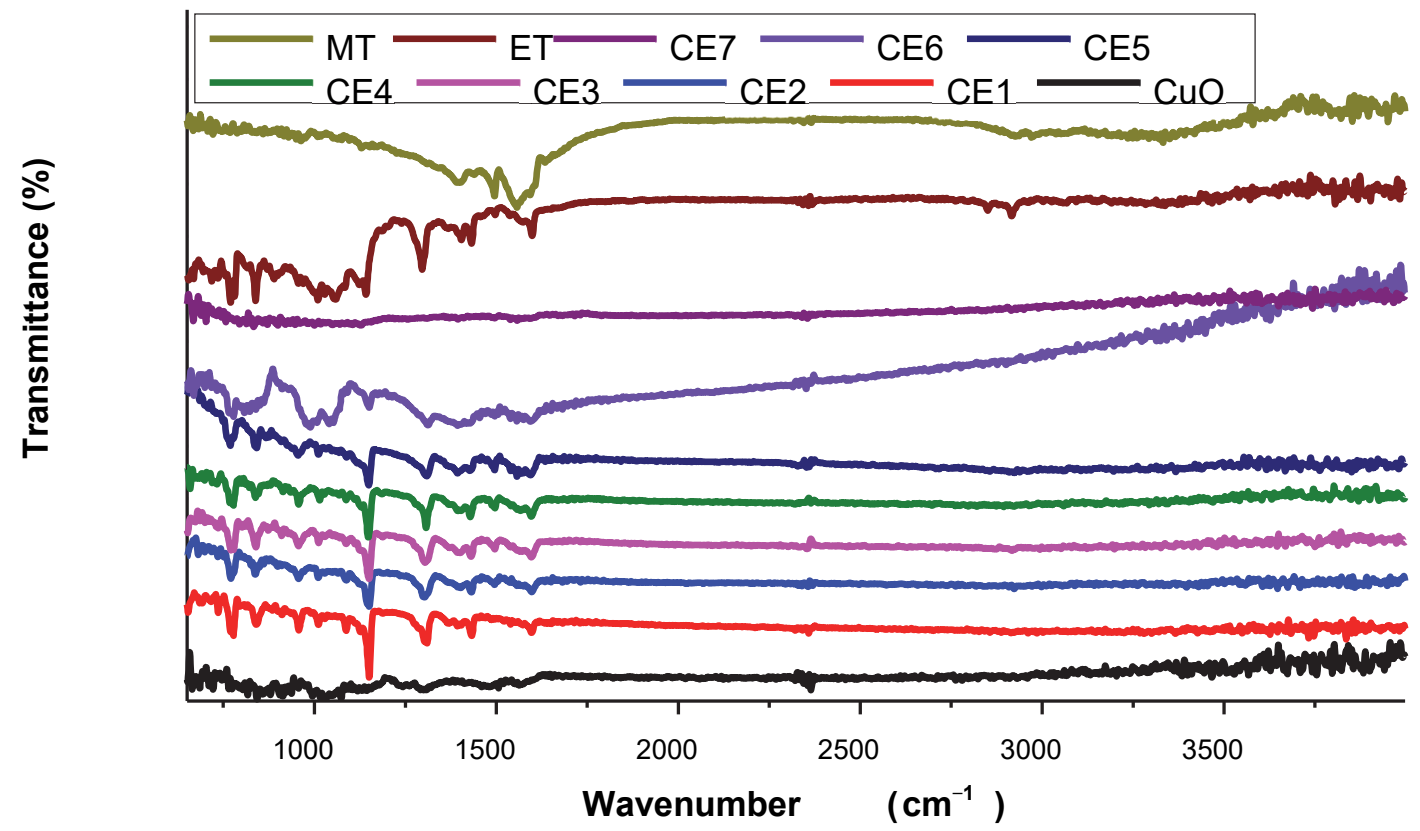

Figure 2. FT-IR spectrum of CuO NPs, ET, MT, and synthesized nanomaterials.

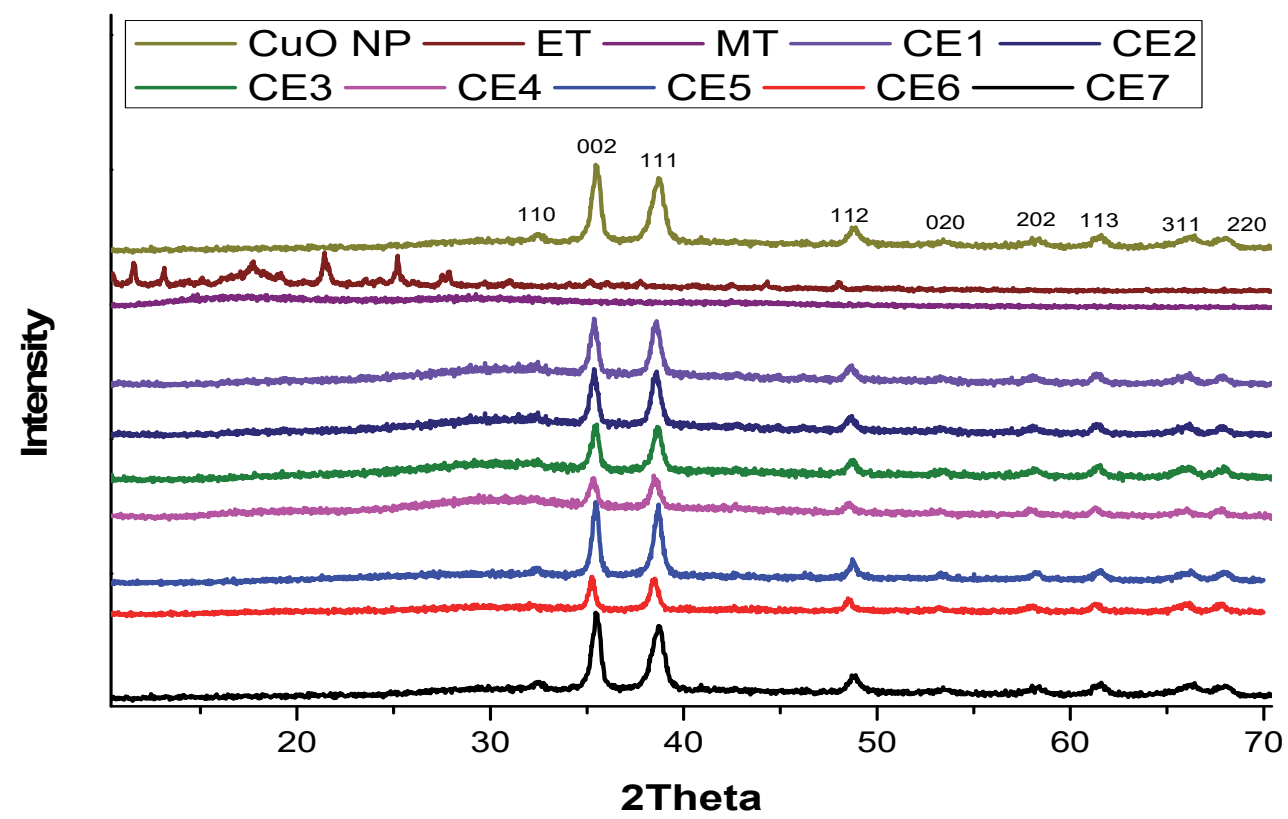

Figure 3. XRD spectrum of $\mathrm{CuO}$ NPs, ET, MT, and synthesized nanomaterials.

\subsubsection{Scanning Electron Microscopy}

The synthesized $\mathrm{CuO}$ NPs were investigated through SEM which showed agglomerated nanorods of $\mathrm{CuO}$ NPs of about $87 \mathrm{~nm}$ size (Figure 4).

\subsubsection{Particle Size Analysis}

The sizes of CE1, CE2, and CE6 were investigated through dynamic light scattering (DLS). The particle sizes of CE1, CE2, and CE6 were 271, 258, and $254 \mathrm{~nm}$, respectively (Figure 5). 
Table 1. Crystallite size of the nanoformulations.

\begin{tabular}{ccc}
\hline S.No. & Name/Code & Crystallite Size (nm) \\
\hline 1 & CuO & 13.7 \\
\hline 2 & ET & 41.64 \\
\hline 3 & MT & Amorphous \\
\hline 4 & CE1 & 19.17 \\
\hline 5 & CE2 & 17.87 \\
\hline 6 & CE3 & 20.97 \\
\hline 7 & CE4 & 22.53 \\
\hline 8 & CE5 & 19.60 \\
\hline 9 & CE6 & 21.98 \\
\hline 10 & CE7 & 18.88 \\
\hline
\end{tabular}

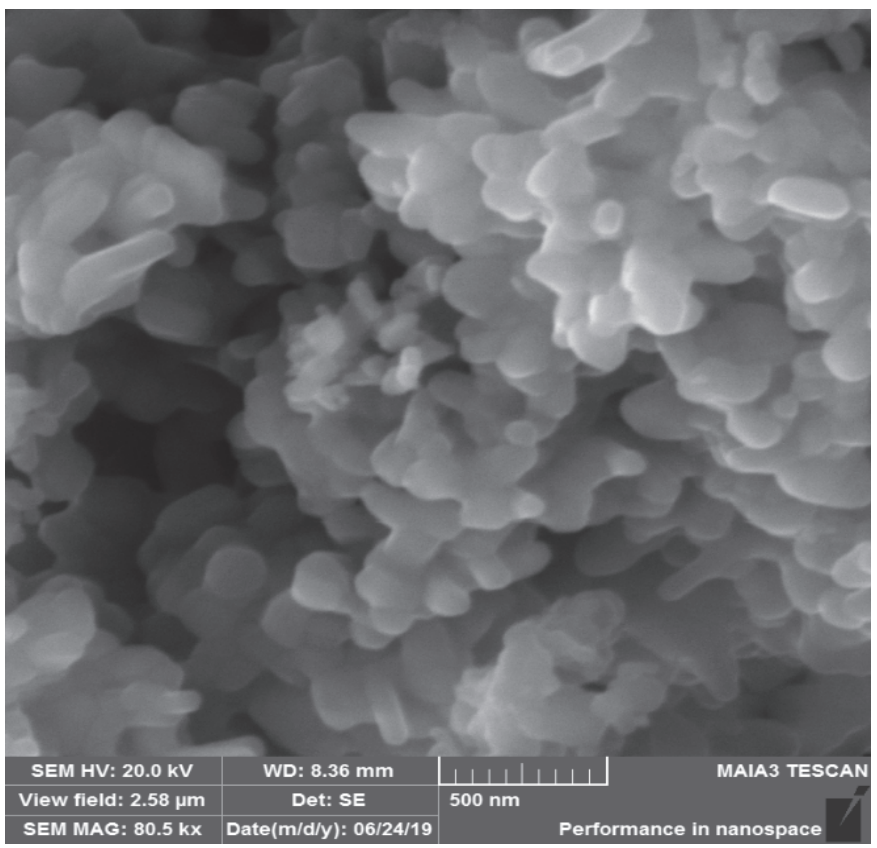

Figure 4. SEM image of CuO NPs.

\subsubsection{Quantification of ET and MT}

The quantity or concentration of ET and MT in each nanoformulation was calculated by UV/Vis spectroscopy at a specific wavelength. The wavelength for quantification of ET was $235 \mathrm{~nm}$ while that of MT was $345 \mathrm{~nm}$. However, the best wavelength for both drugs was $282 \mathrm{~nm}$ (Figure 6). The absorbance of samples followed Beer-Lambert's law.

The quantities of ET and MT in $5 \mathrm{mg}$ of each nanoformulations are given in Table 2. The drug loading efficiency was about 70-75\%, calculated through UV analysis by using the following Equation (1) (encapsulation efficiency (EE)):

$$
\mathrm{EE} \%=\frac{(\text { Total drug added })-(\text { non }- \text { entrapped drug })}{\text { Total drug added }} \times 100
$$

\section{Calibration Curve}

The quantity of ET and MT in different nanoformulations with a mass of $5 \mathrm{mg}$ was analyzed which shows a linear plot on the calibration curve. The results are given in Table 2. 

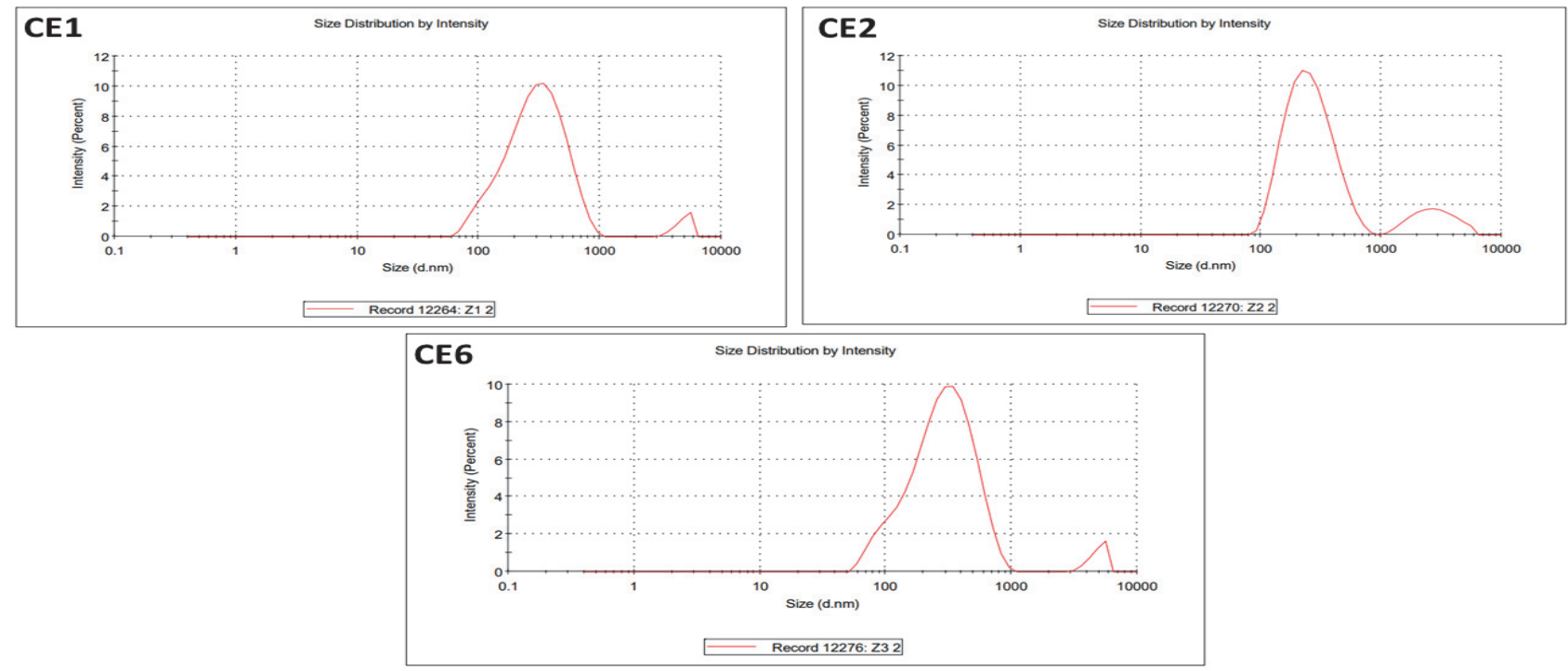

Figure 5. DLS graphs of CE1, CE2, and CE6.

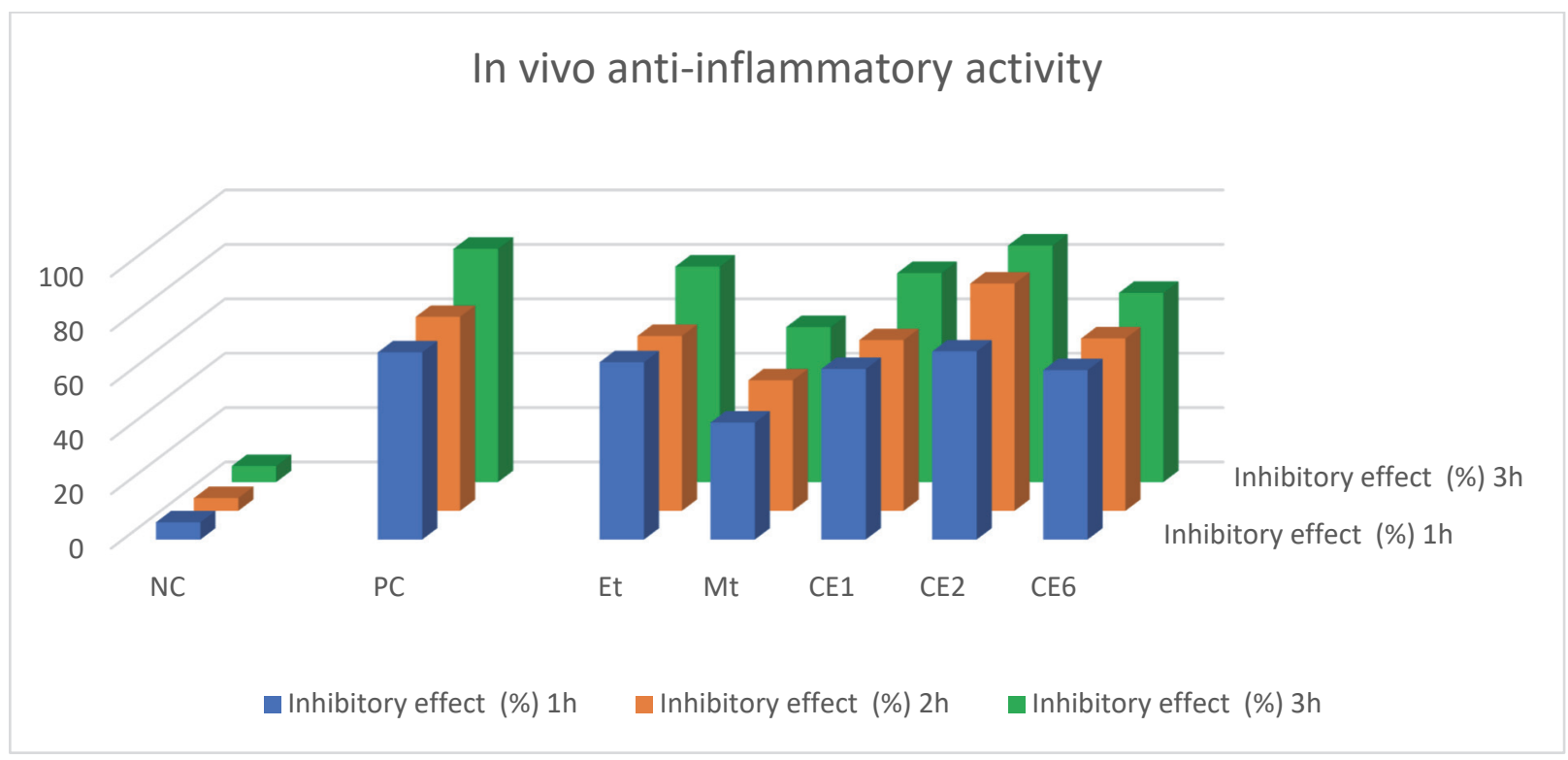

Figure 6. Graphical representation of in vivo anti-inflammatory activity. PC-positive control, NC-negative control.

Table 2. Quantity of etoricoxib and montelukast in $5 \mathrm{mg}$ of each nanoformulation.

\begin{tabular}{ccccc}
\hline S.NO. & $\mathbf{5} \mathbf{~ m g}$ & Etoricoxib $\mathbf{( m g})$ & Montelukast $(\mathbf{m g})$ & $\mathbf{R S D}( \pm \mathbf{)}$ \\
\hline 1. & CE1 & 2.8 & - & 0.07 \\
\hline 2. & CE2 & 2.1 & 0.7 & 0.05 \\
\hline 3. & CE3 & 1.80 & 0.77 & 0.08 \\
\hline 4. & CE4 & 1.45 & 1.35 & 0.06 \\
\hline 5. & CE5 & 0.77 & 1.75 & 0.07 \\
\hline 6. & CE6 & 0.75 & 2.10 & 0.08 \\
\hline 7. & CE7 & - & 2.95 & 0.06 \\
\hline
\end{tabular}




\section{Specificity}

There was no interference from $\mathrm{CuO}$ nanoparticles in the nanoformulation of ET and MT.

Validation of Method

The performance of the system was precise and suitable during the entire analysis of the nanoformulations of ET and MT. Validation of the analysis method for the quantification protocol is reported in the literature both for HPLC and UV/Vis spectroscopy [52].

\subsection{Bioactivities Studies}

\subsubsection{In Vitro Anti-Inflammatory Activity}

The method of inhibition of BSA denaturation was used for in vitro anti-inflammatory activity. It is obvious that the denaturing of proteins leads to inflammation in the body. In this method, solutions of samples were added to a solution of BSA and were then incubated at 37 and $55{ }^{\circ} \mathrm{C}$. The \% inhibition of BSA denaturation was investigated through UV/Vis spectroscopy at a fixed wavelength of $660 \mathrm{~nm}$. The \% inhibitory effect was calculated using the following Equation (2):

$$
\begin{gathered}
\% \text { inhibition } \\
\text { of denaturing }
\end{gathered}=\frac{(\text { absorbance of control })-(\text { absorbance of sample })}{\text { absorbance of control }} \times 100
$$

BSA denaturation was not inhibited in the negative control; therefore, inhibition of nanoformulations and standards was compared with it. Albeit the inhibitory effect of all nanoformulations was high; however, that of CE1, CE2, and CE6 was very high Therefore, these nanoformulations were selected for further evaluation through in vivo studies. The results of \% inhibition of BSA denaturation through nanoformulations are given in Table 3 [53].

Table 3. In vitro anti-inflammatory activity.

\begin{tabular}{cccc}
\hline S.No. & Code & Absorbance at 660 $\mathbf{n m}$ & Inhibition (\%) \pm SEM \\
\hline 1 & $\begin{array}{c}\text { Negative control } \\
(\text { DMSO) }\end{array}$ & 0.6900 & 0 \\
\hline 2 & CE1 & 0.2039 & $70.45 \pm 1.12$ \\
\hline 3 & CE2 & 0.1463 & $78.79 \pm 1.56$ \\
\hline 4 & CE3 & 0.3822 & $44.61 \pm 1.12$ \\
\hline 5 & CE4 & 0.7444 & $7.884 \pm 1.25$ \\
\hline 6 & CE5 & 0.6335 & $8.188 \pm 1.46$ \\
\hline 7 & CE6 & 0.2040 & $70.43 \pm 1.52$ \\
\hline 8 & CE7 & 0.2802 & $59.39 \pm 1.14$ \\
\hline 9 & Etoricoxib (ET) & 0.0221 & $96.80 \pm 1.36$ \\
\hline 10 & Montelukast (MT) & 0.1476 & $78.61 \pm 1.95$ \\
\hline 11 & CuO & 0.1677 & $75.69 \pm 1.80$ \\
\hline 12 & $\begin{array}{c}\text { Positive control } \\
\text { (diclofenac sodium) }\end{array}$ & 0.0755 & $89.06 \pm 1.75$ \\
\hline & & &
\end{tabular}

\subsubsection{In Vivo Anti-Inflammatory Activity}

In vivo anti-inflammatory activity was carried out through the carrageenan-induced hind paw edema method on albino mice at the Department of pharmacy, Quaid e Azam University, Islamabad. Mice of both sexes were used. Mice were treated with nanoformulations at a dose of $5 \mathrm{mg} / \mathrm{kg}$ body weight while doses of drugs were $10 \mathrm{mg} / \mathrm{kg}$ body weight through i.p. injection. They were treated with $0.1 \mathrm{~mL}$ of carrageenan $1 \%$ solution through the left hind paw and the paw volume was measured using a Plethysmometer. 
The $\%$ inhibition of inflammation was estimated from the decrease in the volume of the hind paw of mice. The \% inhibition of inflammation was calculated using the following Equation (3) [54,55]:

$$
\% \text { inhibition }=\frac{\left(\mathrm{V}_{\text {control }}-\mathrm{V}_{\text {test }}\right)}{\mathrm{V}_{\text {control }}} \times 100
$$

The inhibition of inflammation was low in the first hour but increased in the second and third hour. The \% inhibitory effect of CE2 was high against inflammation, which is shown in Table 4 and Figure 6.

Table 4. In vivo anti-inflammatory activity.

\begin{tabular}{ccccc}
\hline \multirow{2}{*}{ Drug } & $\begin{array}{c}\text { Dose } \\
(\mathbf{m g} / \mathbf{k g})\end{array}$ & $\mathbf{1 ~ h}$ & $\mathbf{2 ~ h}$ & $\mathbf{3 ~ h}$ \\
\cline { 3 - 5 } & - & $6.37 \pm 1.08$ & $4.75 \pm 1.03$ & $5.93 \pm 1.02$ \\
\hline $\begin{array}{c}\text { Negative control } \\
\text { (normal saline) }\end{array}$ & 10 & $68.84 \pm 1.23$ & $71.33 \pm 1.12$ & $85.78 \pm 1.24$ \\
\hline $\begin{array}{c}\text { Positive control } \\
\text { (diclofenac sodium) }\end{array}$ & 10 & $65.19 \pm 1.21$ & $64.30 \pm 1.53$ & $79.26 \pm 1.42$ \\
\hline Et & 10 & $43 \pm 1.24$ & $48 \pm 1.35$ & $57 \pm 1.45$ \\
\hline Mt & 5 & $62.72 \pm 1.21$ & $62.77 \pm 1.24$ & $76.84 \pm 1.22$ \\
\hline CE1 & 5 & $69.17 \pm 1.25$ & $83.56 \pm 1.31$ & $86.99 \pm 1.32$ \\
\hline CE2 & 5 & $62.29 \pm 1.39$ & $63.38 \pm 1.42$ & $69.59 \pm 1.38$ \\
\hline CE6 & & & &
\end{tabular}

\subsubsection{In Vivo Analgesic Activity}

In vivo analgesic activity was performed in albino mice through the hot plate method. Mice were treated with doses of nanoformulations intraperitonially. They were placed on a hot plate at $55{ }^{\circ} \mathrm{C}$ for a $30 \mathrm{~s}$ cut-off time. The body movements of mice were keenly observed. The $\%$ inhibition of pain was measured from the time they tolerate on the hot plate. If pain is more inhibited, the mice will spend more time on the hot plate and vice versa. The \% pain inhibition of CE2 was very high as compared to other nanoformulations which is shown in Table 5 and Figure 7.

Table 5. In vivo analgesic activity.

\begin{tabular}{ccccc}
\hline \multirow{2}{*}{ Drug } & $\begin{array}{c}\text { Dose } \\
(\mathbf{m g} / \mathbf{k g})\end{array}$ & $\mathbf{1 ~ h}$ & $\mathbf{2 ~ h}$ & $\mathbf{3 ~ h}$ \\
\cline { 3 - 5 } & & $7.79 \pm 1.02$ & $6.20 \pm 1.10$ & $3.03 \pm 1.21$ \\
\hline $\begin{array}{c}\text { Negative control } \\
\text { (normal saline) }\end{array}$ & - & $58.34 \pm 1.21$ & $83.38 \pm 1.24$ & $83.22 \pm 1.45$ \\
\hline $\begin{array}{c}\text { Positive control } \\
\text { (diclofenac sodium) }\end{array}$ & 10 & $24.30 \pm 1.24$ & $35.37 \pm 1.10$ & $48.61 \pm 1.15$ \\
\hline Et & 10 & $9.53 \pm 1.32$ & $7.95 \pm 1.24$ & $6.41 \pm 1.42$ \\
\hline Mt & $10[54]$ & $35.97 \pm 1.54$ & $49.41 \pm 1.41$ & $63.86 \pm 1.24$ \\
\hline CE1 & 5 & $26.37 \pm 1.45$ & $51.53 \pm 1.32$ & $73.88 \pm 1.52$ \\
\hline CE2 & 5 & $19.19 \pm 1.12$ & $34.71 \pm 1.21$ & $51.72 \pm 1.54$ \\
\hline CE6 & 5 & & &
\end{tabular}

\subsubsection{In Vivo Anti Pyretic Activity}

In vivo anti-pyretic activity was carried out in albino mice through the yeast-induced pyrexia method. To induce pyrexia, $10 \mathrm{~mL} / \mathrm{kg}$ of $20 \%$ yeast solution was intraperitoneally injected into mice. The body temperature of mice was measured before the treatment of yeast solution through a lubricated thermometer. Mice whose body temperature increased 
by $0.6{ }^{\circ} \mathrm{C}$ were selected for this activity. These mice were treated with nanoformulations intraperitoneally to inhibit pyrexia. The temperature of mice was measured for $4 \mathrm{~h}$ after each hour, which was controlled in the first hour by CE1, CE2, and CE3 as shown in Table 6. The body temperature of mice is graphically represented in Figure 8 before and after treatment of the samples. The blue color indicates mice with normal body temperature $\left(98.6^{\circ} \mathrm{F}\right)$ while the orange color indicates mice with a high body temperature due to the treatment of yeast. The other four colors indicate the body temperature of mice following the treatment of samples.

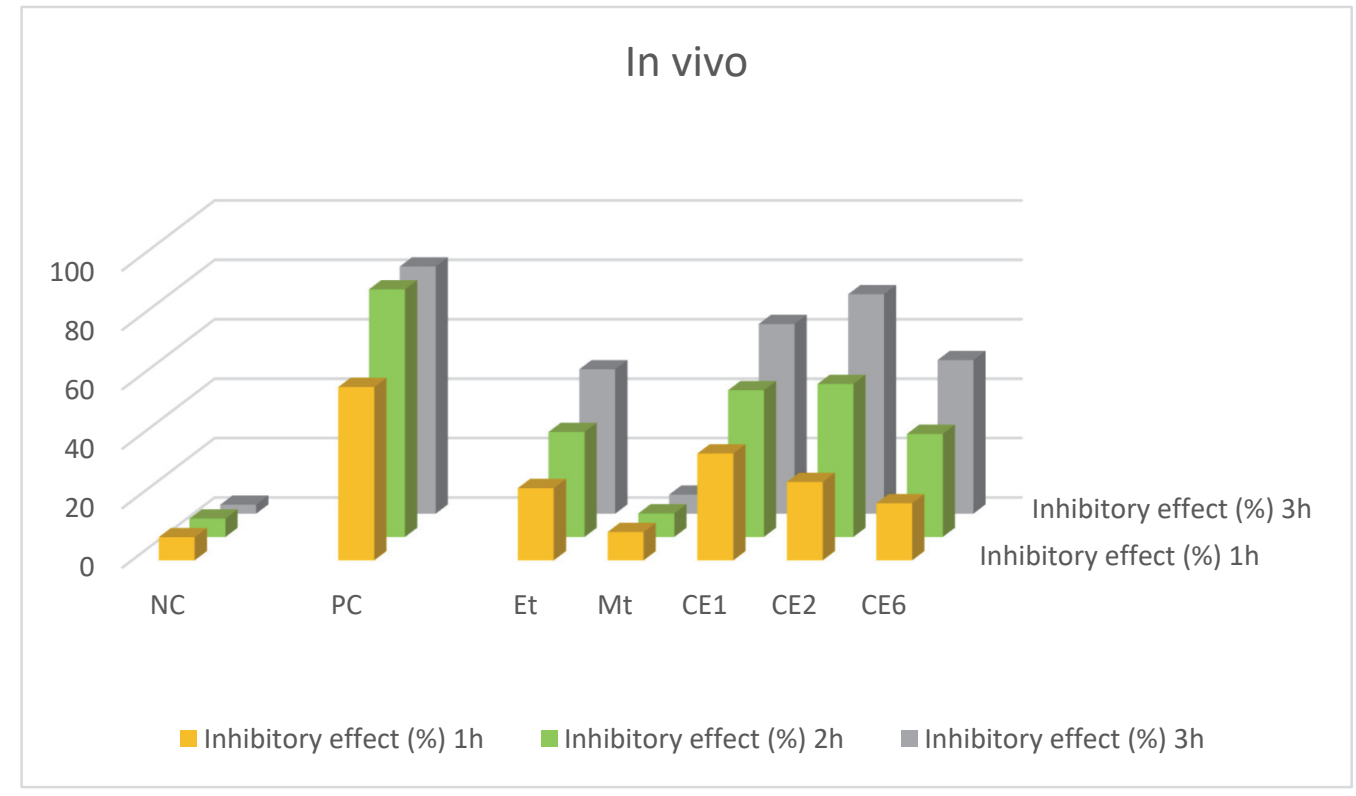

Figure 7. Graphical representation of in vivo analgesic activity.

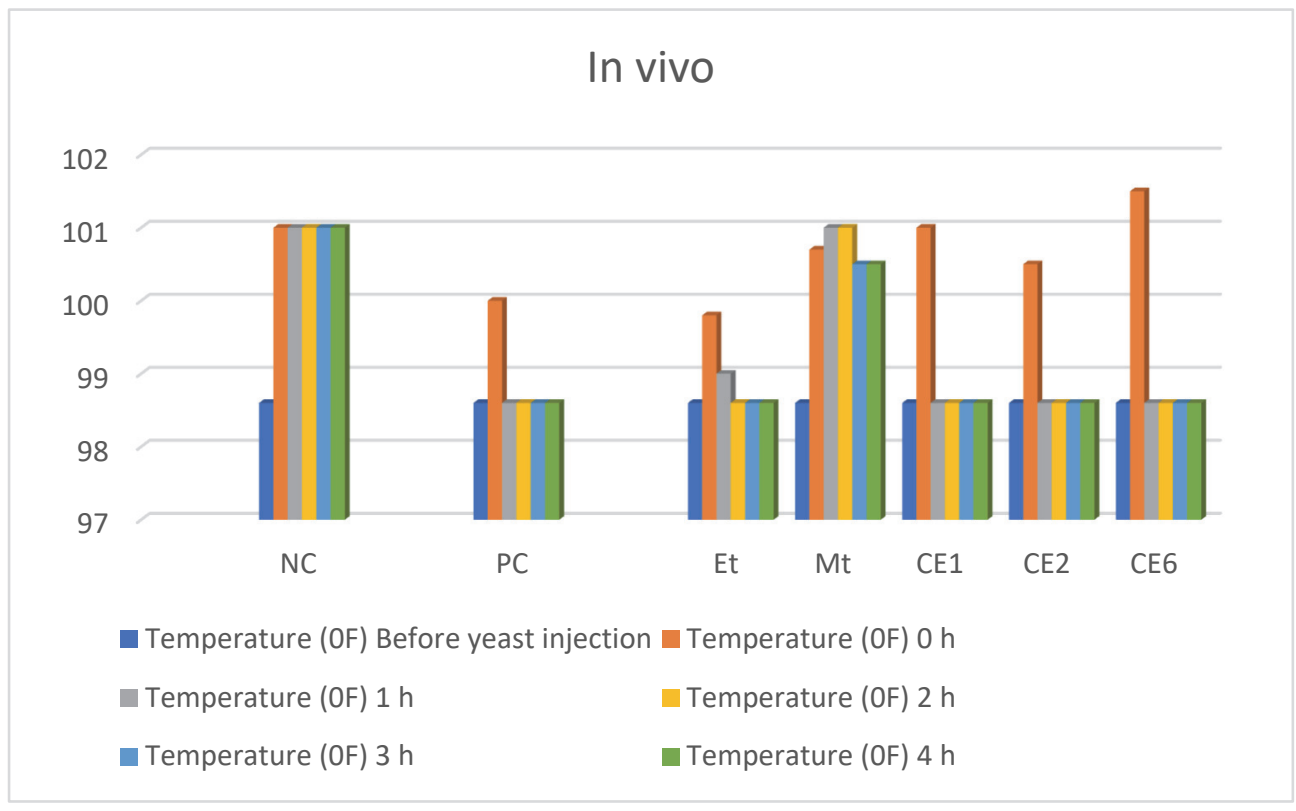

Figure 8. Graphical representation of in vivo anti-pyretic activity. 
Table 6. In vivo anti-pyretic activity.

\begin{tabular}{|c|c|c|c|c|c|c|c|}
\hline \multirow{2}{*}{ Drug } & \multirow{2}{*}{$\begin{array}{c}\text { Dose } \\
(\mathrm{mg} / \mathrm{kg})\end{array}$} & \multicolumn{6}{|c|}{ Temperature $\left({ }^{\circ} \mathbf{F}\right)$} \\
\hline & & Before Yeast Injection & $\mathrm{Oh}$ & $1 \mathrm{~h}$ & $2 \mathrm{~h}$ & $3 \mathrm{~h}$ & $4 \mathrm{~h}$ \\
\hline $\begin{array}{l}\text { Negative control } \\
\text { (normal saline) }\end{array}$ & - & 98.6 & 101 & 101 & 101 & 101 & 101 \\
\hline $\begin{array}{l}\text { Positive control } \\
\text { (paracetamol) }\end{array}$ & $20[56]$ & 98.6 & 100 & 98.6 & 98.6 & 98.6 & 98.6 \\
\hline Et & 20 & 98.6 & 99.8 & 99 & 98.6 & 98.6 & 98.6 \\
\hline $\mathrm{Mt}$ & 20 [54] & 98.6 & 100.7 & 101 & 101 & 100.5 & 100.5 \\
\hline CE1 & 5 & 98.6 & 101 & 98.6 & 98.6 & 98.6 & 98.6 \\
\hline CE2 & 5 & 98.6 & 100.5 & 98.6 & 98.6 & 98.6 & 98.6 \\
\hline CE6 & 5 & 98.6 & 101.5 & 98.6 & 98.6 & 98.6 & 98.6 \\
\hline
\end{tabular}

\subsubsection{In Vivo Acute Toxicity Activity}

In vivo acute toxicity activity was carried out in albino mice through the median lethal dose (LD50) method. Different doses of nanoformulations were given to mice and observed for $24 \mathrm{~h}$. The mice were normal when treated with doses of 5, 10, 25, 50, and $100 \mathrm{mg} / \mathrm{kg}$ body weight; however, died when the dose was increased to $200 \mathrm{mg} / \mathrm{kg}$ body weight. It was confirmed that the nanoformulations are acutely toxic at or above $200 \mathrm{mg} / \mathrm{kg}$ body weight.

\section{Materials and Methods}

\subsection{Materials}

Copper nitrate trihydrate $\left(\mathrm{Cu}\left(\mathrm{NO}_{3}\right)_{2} \cdot 3 \mathrm{H}_{2} \mathrm{O}\right)$, sodium hydroxide $(\mathrm{NaOH})$, ethanol, ET, poly ethylene glycol (PEG, 6000), and polyvinyl acetate (PVA) were obtained from Merck (Darmstadt, Germany). UV/Vis spectra were recorded through Perkin Elmer (Waltham, MA, USA), UV/Vis spectrometer, Lambda 25. The FT-IR spectrum was performed on a JASCO FT/IR-6600 spectrometer. X-ray diffractometry (XRD) was conducted by using a D8 advance Bruker X-ray diffractometer equipped with a $\mathrm{Cu}$ anode (Bruker, Bremen, Germany).

\subsection{Synthesis of Copper Oxide Nanoparticles}

$\mathrm{CuO}$ NPs were prepared through the coprecipitation method. $\mathrm{Cu}\left(\mathrm{NO}_{3}\right)_{2} \cdot 3 \mathrm{H}_{2} \mathrm{O}$ was used as a precursor salt. $\mathrm{Cu}\left(\mathrm{NO}_{3}\right)_{2} \cdot 3 \mathrm{H}_{2} \mathrm{O}$ salt was reduced to $\mathrm{NaOH}$ to prepare $\mathrm{CuO}$ NPs. A $100 \mathrm{mM}$ solution of $\mathrm{Cu}\left(\mathrm{NO}_{3}\right)_{2} \cdot 3 \mathrm{H}_{2} \mathrm{O}$ was prepared in $100 \mathrm{~mL}$ deionized water. PEG-6000 was used as a surfactant in this synthetic work. A $100 \mathrm{mM}$ solution of $\mathrm{NaOH}$ was very slowly added to the solution of $\mathrm{Cu}\left(\mathrm{NO}_{3}\right)_{2} \cdot 3 \mathrm{H}_{2} \mathrm{O}$ with constant stirring, which led to an increase in the $\mathrm{pH}$ of the solution. The addition of $\mathrm{NaOH}$ was stopped when the $\mathrm{pH}$ become basic. The appearance of blackish particles represented the synthesis of $\mathrm{CuO}$ NPs. The $\mathrm{pH}$ of the solution was maintained at $\mathrm{pH} 7$ by washing with deionized water. The solution was filtered through Whatman filter paper and the residue was dried, ground, and then calcinated at $500{ }^{\circ} \mathrm{C}$ for $4 \mathrm{~h} \mathrm{[57].}$

\subsection{Synthesis of Etoricoxib and Montelukast Conjugated CuO Nanomaterials (CE)}

$\mathrm{CuO}$ NPs were used as nanocarriers for the ET and MT. Separate solutions of $\mathrm{CuO}$ NPs, ET, and MT were prepared in ethanol. The $\mathrm{CuO}$ NPs solution was sonicated for $1 \mathrm{~h}$ to completely dissolve it. Different ratios of ET and MT solutions were added to the $\mathrm{CuO}$ NPs solution (Table 7). The solution was kept for $2 \mathrm{~h}$ post stirring. Then, the solution was sonicated for $2 \mathrm{~h}$ and then centrifuged at $6000 \mathrm{rpm}$ for $1 \mathrm{~h}$. The synthesized nanoformulations were dried at room temperature. Drug loading efficiency was $70-75 \%$. PVA was used as an encapsulation agent for ET- and MT-conjugated $\mathrm{CuO}$ nanomaterials. Moreover, 2.5\% PVA was added to the synthesized nanoformulation. 
Table 7. Composition of nanoformulations.

\begin{tabular}{|c|c|c|c|c|c|}
\hline S.No. & Code & $\mathrm{CuO}(\%)$ & Etoricoxib (\%) & Montelukast (\%) & PVA wt $\%$ \\
\hline 1 & CE1 & 20 & 80 & - & \multirow{7}{*}{2.5} \\
\hline 2 & CE2 & 20 & 60 & 20 & \\
\hline 3 & CE3 & 20 & 50 & 30 & \\
\hline 4 & CE4 & 20 & 40 & 40 & \\
\hline 5 & CE5 & 20 & 30 & 50 & \\
\hline 6 & CE6 & 20 & 20 & 60 & \\
\hline 7 & CE7 & 20 & - & 80 & \\
\hline 8 & $\mathrm{ET}$ & - & 100 & - & - \\
\hline 9 & MT & - & - & 100 & - \\
\hline 10 & $\mathrm{CuO}$ & 100 & - & - & - \\
\hline
\end{tabular}

\subsubsection{Quantification Protocol}

The objective of the spectroscopic quantification of ET and MT was to determine their quantity in the nanoformulations. The quantification of ET and MT was carried out both simultaneously as well as separately for each drug. Although this may be carried out through HPLC or UV/Vis spectroscopy, here the analysis was performed through UV/Vis spectroscopy in the range of 200-800 nm. Therefore, different solutions of ET and MT were prepared in ethanol. Different ratios of ET and MT were added in different solutions. Separate and combined solutions were prepared for the drugs. The quantity of drugs was analyzed through UV/Vis spectroscopy for each solution [58]. The wavelength for quantification of ET was $235 \mathrm{~nm}$ while that of MT was $345 \mathrm{~nm}$. However, the best wavelength for both drugs was $282 \mathrm{~nm}$.

\subsubsection{Samples Preparation}

Five milligrams of ET was added to $20 \mathrm{~mL}$ of ethanol and sonicated for $30 \mathrm{~min}$ for complete dissolution. Five milligrams of MT was also added to $20 \mathrm{~mL}$ of ethanol in another beaker and completely dissolved. Then, different ratios of ET and MT (1:3, 1.5:2.5, 2:2, 2.5:1.5, and 3:1) were added to different beakers containing ethanol as the solvent and were completely dissolved through sonication. These solutions were diluted and analyzed through UV/Vis spectroscopy.

Solutions of $\mathrm{CuO}$ NPs were also prepared in ethanol. Then, solutions of ET and MT of the above ratios were added to a solution of $\mathrm{CuO}$ NPs in separate beakers. Next, the solution was sonicated and centrifuged at $6000 \mathrm{rpm}$. The supernatant was separated for each solution and was analyzed through UV/Vis spectroscopy. The difference in the quantity of ET as well as of MT, before and after addition to CuO nanoparticles, was calculated from analyzing the UV/Vis spectra [59].

\subsection{Characterization}

The FTIR analysis was carried out using the JASCO FT/IR-6600 spectrometer at a range of $400-4000 \mathrm{~cm}^{-1}$. The samples were taken in solid powder form. For each sample, the values of $\%$ transmittance were obtained in the form of an FTIR spectrum. FTIR measures the vibrations of atoms, molecules, and functional groups which correspond to the matching frequency of the infrared beam. Therefore, the FTIR spectrum consists of the functional group region and fingerprint region [60]. The XRD spectra were performed through a D8 advance Bruker X-ray diffractometer (Bruker, Bremen, Germany) for the investigation of crystallite size, miller indices, and phase determination. The spectra were calculated in the range of 10-90 20. Samples were taken in solid powder form for XRD analysis. The spectra were matched with JCPDS cards for verification. In this analysis, the principle of Bragg's law $(2 \mathrm{~d} \sin \theta=\mathrm{n} \lambda)$ was followed [61]. The crystal structure was 
calculated through Scherrer's formula $(\mathrm{Ls}=0.92 \lambda / \beta \mathrm{s} \cos \theta \mathrm{B})$. Zetasizer or dynamic light scattering (DLS) is the technique used for the determination of the size of particles in the suspension. DLS was performed in the Pharmacy Department, QAU, Islamabad. DLS can measure particle sizes ranging from $1 \mathrm{~nm}$ to $10 \mu \mathrm{m}$. The DLS analysis is based on the Brownian motion of particles. The Stokes-Einstein equation was used to calculate the particle size ( $\mathrm{D}=\mathrm{kT} / 6 \mathrm{rhR})$ [62]. Scanning electron microscopy (SEM) was used to investigate the size, shape, texture, and morphology of nanoparticles. SEM analysis was carried out at PINSTIC Islamabad. The samples were taken in solid powder form and investigated by SEM. The basic principle of SEM for the investigation and analysis of substances includes scanning under a beam of electrons. In SEM analysis, the range of voltage is about $30 \mathrm{keV}$.

\subsection{Bioactivities}

\subsubsection{In Vitro Anti-Inflammatory Activity}

The primary cause of inflammation is the denaturing of proteins in the body. Therefore, for measurement of the potency of drugs and nanoformulations in vitro, anti-inflammatory activity was performed through the inhibition of the bovine serum albumin (BSA) denaturing method. In this method, $5 \mathrm{mg} / \mathrm{mL}$ solution of each sample was prepared in DMSO and that of BSA ( $1 \%$ solution) was prepared in deionized water. Moreover, a $2 \mathrm{mg} / \mathrm{mL}$ solution of Diclofenac sodium was used as a standard. Then, $0.9 \mathrm{~mL}$ of BSA solution was added to a $0.1 \mathrm{~mL}$ solution of each sample and the standard. The solutions were incubated at $37^{\circ} \mathrm{C}$ for $20 \mathrm{~min}$ and then at $55^{\circ} \mathrm{C}$ for a further $20 \mathrm{~min}$. These samples were evaluated through $\mathrm{UV} /$ Vis spectroscopy at $660 \mathrm{~nm}[63]$.

\subsubsection{In Vivo Anti-Inflammatory Activity}

Albino mice were obtained from the National Institute of Health, Islamabad, and an ethics approval letter was obtained from the ethics committee of Islamia College, Peshawar, Pakistan, for the proper handling and care of albino mice.

In vivo anti-inflammatory activity was performed on albino mice through the carrageenaninduced hind paw oedema method. The hind paw volume was measured before and after the treatment of carrageenan using a Plethysmometer (UGO BASILE 7140). Doses of samples were prepared in normal saline water and were administered through intraperitoneal (i.p.) injection as $5 \mathrm{mg} / \mathrm{kg}$ body weight. To induce swelling, $0.1 \mathrm{~mL}$ of $1 \%$ carrageenan solution was injected into the left hind paw of each mouse. The paw volume was measured after one hour of drug treatment. The drug was not given to the negative control group $[64,65]$.

\subsubsection{In Vivo Analgesic Activity}

In vivo analgesic activity was carried out in albino mice using the hot-plate method of Eddy and Leimbach (1953) [66]. Mice of both sexes were used in this activity. The average weight of mice was 26-28 g. Doses of nanoformulations were given through i.p. injection as $5 \mathrm{mg} / \mathrm{kg}$ body weight. Then, mice were placed on a hot plate for a $35 \mathrm{~s}$ cut-off temperature. The temperature of the hot plate was adjusted to $55^{\circ} \mathrm{C}$ [67].

\subsubsection{In Vivo Anti Pyretic Activity}

The yeast-induced pyrexia method was used for evaluating in vivo anti-pyretic activity in albino mice. To induce pyrexia, $20 \%$ of aqueous brewer's yeast solution was subcutaneously injected into mice at a dose of $10 \mathrm{~mL} / \mathrm{kg}$ body weight [68]. The body temperature of each mouse was measured through a rectal thermometer before the treatment of the yeast solution. After $18 \mathrm{~h}$, the body temperature of mice was again measured. Mice whose body temperature increased by $0.6^{\circ} \mathrm{C}$ were selected. Doses of nanoformulations and standards were given to each mouse through i.p. injection. The body temperature of mice was measured for $4 \mathrm{~h} \mathrm{[56].}$ 


\subsubsection{In Vivo Acute Toxicity Activity}

In vivo acute toxicity activity was carried out in albino mice through the median lethal dose (LD50) method [69]. Different doses of nanoformulations were given to mice and were observed for $24 \mathrm{~h}$. The doses were 5, 10, 20, 50, 100, and $200 \mathrm{mg} / \mathrm{kg}$ body weight. The purpose of this activity was to measure the maximum amount of nanoformulations that were safe for organisms.

\subsubsection{Statistical Analysis}

The studied bioactivities data are expressed as the standard error mean (SEM). The mean \pm standard deviation (SD) was calculated for the data by the Equation (4):

$$
\% \pm \mathrm{SEM}=\frac{\% \pm \mathrm{SD}}{\sqrt{3}}
$$

\section{Conclusions}

$\mathrm{CuO}$ NPs were used as nanocarriers of ET (selective COX-2 inhibitor drug) and MT (leukotriene product inhibitor drug) in different ratios. $\mathrm{CuONPs}$ were synthesized through the coprecipitation method and investigated using different tools. The synthesized nanoformulations were evaluated through in vitro and in vivo bioactivities which confirmed that these nanoformulations were more potent than those of parent drugs. The in vitro antiinflammatory activity indicated that CE1, CE2, and CE6 are of high potency; therefore, these three nanoformulations were further evaluated through in vivo bioactivities. The in vivo bioactivities showed that low doses $(5 \mathrm{mg} / \mathrm{kg})$ of nanoformulations were more potent than that of high doses $(10$ and $20 \mathrm{mg} / \mathrm{kg}$ ) of free drugs.

Author Contributions: Data curation, S.Q. and S.M.; formal analysis, S.S., S.Q. and S.M.; funding acquisition, A.A. and R.U.; investigation, A.A., R.U., S.S., S.S.N. and S.Q.; methodology, S.M. and A.A.; project administration, S.A.; resources, S.S.N., A.A. and R.U.; software, R.U.; supervision, S.A. All authors have read and agreed to the published version of the manuscript.

Funding: This research was funded by Princess Nourah bint Abdulrahman University Researchers Supporting Project number (PNURSP2022R33), Princess Nourah bint Abdulrahman University, Riyadh, Saudi Arabia.

Institutional Review Board Statement: This study has approved by institutional ethical committee Islamia College University Peshawar (Ref 108/chem-Dated 17 January 2021).

Informed Consent Statement: Not applicable.

Data Availability Statement: All available data incorporated in the MS.

Acknowledgments: Authors wish to thank Princess Nourah bint Abdulrahman University Researchers Supporting Project number (PNURSP2022R33), Princess Nourah bint Abdulrahman University, Riyadh, Saudi Arabia, for financial support.

Conflicts of Interest: The authors declare that there is no conflict of interest.

Sample Availability: Samples of the compounds are available with First author.

\section{References}

1. Shah, S.S.; Shaikh, M.N.; Khan, M.Y.; Alfasane, M.A.; Rahman, M.M.; Aziz, M.A. Present status and future prospects of jute in nanotechnology: A review. Chem. Rec. 2021, 21, 1631-1665. [CrossRef] [PubMed]

2. Feynman, R. There's plenty of room at the bottom. In Feynman and Computation; CRC Press: Boca Raton, FL, USA, 2018 ; pp. 63-76.

3. Love, L.; Post, B.; Noakes, M.; Nycz, A.; Kunc, V. There's Plenty of Room at the Top; Elsevier: Amsterdam, The Netherlands, 2021; Volume 39, p. 101727.

4. $\quad$ Nasrollahzadeh, M.; Sajadi, S.M.; Sajjadi, M.; Issaabadi, Z. An introduction to nanotechnology. In Interface Science and Technology; Elsevier: Amsterdam, The Netherlands, 2019; Volume 28, pp. 1-27.

5. Waris, A.; Din, M.; Ali, A.; Ali, M.; Afridi, S.; Baset, A.; Khan, A.U. A comprehensive review of green synthesis of copper oxide nanoparticles and their diverse biomedical applications. Inorg. Chem. Commun. 2021, 123, 108369. [CrossRef] 
6. Marcolongo, D.M.S.; Nocito, F.; Ditaranto, N.; Comparelli, R.; Aresta, M.; Dibenedetto, A. Opto-Electronic Characterization of Photocatalysts Based on p, n-Junction Ternary and Quaternary Mixed Oxides Semiconductors $\left(\mathrm{Cu}_{2} \mathrm{O}_{-}-\mathrm{In}_{2} \mathrm{O}_{3}\right.$ and $\mathrm{Cu}_{2} \mathrm{O}-\mathrm{In}_{2} \mathrm{O}_{3}-$ $\mathrm{TiO}_{2}$ ). Catalysts 2022, 12, 153. [CrossRef]

7. Rupashree, M.; Soppin, K.; Pratibha, S.; Chethan, B. Cost effective photocatalytic and humidity sensing performance of green tea mediated copper oxide nanoparticles. Inorg. Chem. Commun. 2021, 134, 108974. [CrossRef]

8. Trukawka, M.; Wenelska, K.; Singer, L.; Klingeler, R.; Chen, X.; Mijowska, E. Hollow carbon spheres loaded with uniform dispersion of copper oxide nanoparticles for anode in lithium-ion batteries. J. Alloy. Compd. 2021, 853, 156700. [CrossRef]

9. Barman, K.; Dutta, P.; Chowdhury, D.; Baruah, P.K. Green biosynthesis of copper oxide nanoparticles using waste colocasia esculenta leaves extract and their application as recyclable catalyst towards the synthesis of 1, 2, 3-triazoles. BioNanoScience 2021, 11, 189-199. [CrossRef]

10. Ghodke, S.A.; Sonawane, S.H.; Bhanvase, B.A.; Potoroko, I. Advanced engineered nanomaterials for the treatment of wastewater. In Handbook of Nanomaterials for Industrial Applications; Elsevier: Amsterdam, The Netherlands, 2018; pp. 959-970.

11. Kaduševičius, E. Novel applications of NSAIDs: Insight and future perspectives in cardiovascular, neurodegenerative, diabetes and cancer disease therapy. Int. J. Mol. Sci. 2021, 22, 6637. [CrossRef]

12. Shaheen, N.J.; Hansen, R.A.; Morgan, D.R.; Gangarosa, L.M.; Ringel, Y.; Thiny, M.T.; Russo, M.W.; Sandler, R.S. The burden of gastrointestinal and liver diseases, 2006. Am. J. Gastroenterol. 2006, 101, 2128-2138. [CrossRef] [PubMed]

13. Jones, R. Nonsteroidal anti-inflammatory drug prescribing: Past, present, and future. Am. J. Med. 2001, 110, S4-S7. [CrossRef]

14. Sostres, C.; Gargallo, C.J.; Arroyo, M.T.; Lanas, A. Adverse effects of non-steroidal anti-inflammatory drugs (NSAIDs, aspirin and coxibs) on upper gastrointestinal tract. Best Pract. Res. Clin. Gastroenterol. 2010, 24, 121-132. [CrossRef]

15. Ambati, G.G.; Jachak, S.M. Natural product inhibitors of cyclooxygenase (COX) enzyme: A review on current status and future perspectives. Curr. Med. Chem. 2021, 28, 1877-1905. [CrossRef]

16. Salvo, F.; Fourrier-Réglat, A.; Bazin, F.; Robinson, P.; Riera-Guardia, N.; Haag, M.; Caputi, A.; Moore, N.; Sturkenboom, M.; Pariente, A. Cardiovascular and gastrointestinal safety of NSAIDs: A systematic review of meta-analyses of randomized clinical trials. Clin. Pharmacol. Ther. 2011, 89, 855-866. [CrossRef] [PubMed]

17. Solomon, D.H.; Husni, M.E.; Libby, P.A.; Yeomans, N.D.; Lincoff, A.M.; Luscher, T.F.; Menon, V.; Brennan, D.M.; Wisniewski, L.M.; Nissen, S.E. The risk of major NSAID toxicity with celecoxib, ibuprofen, or naproxen: A secondary analysis of the PRECISION trial. Am. J. Med. 2017, 130, 1415-1422.e4. [CrossRef] [PubMed]

18. Hameed, H.A.; Khan, S.; Shahid, M.; Ullah, R.; Bari, A.; Ali, S.S.; Hussain, Z.; Sohail, M.; Khan, S.U.; Htar, T.T. Engineering of Naproxen Loaded Polymer Hybrid Enteric Microspheres for Modified Release Tablets: Development, Characterization, in silico Modelling and in vivo Evaluation. Drug Des. Dev. Ther. 2020, 14, 27-41. [CrossRef] [PubMed]

19. Chen, J.S.; Alfajaro, M.M.; Chow, R.D.; Wei, J.; Filler, R.B.; Eisenbarth, S.C.; Wilen, C.B. Nonsteroidal anti-inflammatory drugs dampen the cytokine and antibody response to SARS-CoV-2 infection. J. Virol. 2021, 95, e00014-e00021. [CrossRef]

20. Şahin, Z.; Kalkan, M.; Berk, B.; Yurttaş, L.; Bender, C.; Kaleli, S.N.B.; Demirayak, Ş. Synthesis, characterization, COX1/2 inhibition and molecular modeling studies on novel 2-thio-diarylimidazoles. Turk. J. Chem. 2021, 45, 1841-1853.

21. Abdellatif, K.R.; Abdelall, E.K.; Elshemy, H.A.; Philoppes, J.N.; Hassanein, E.H.; Kahk, N.M. Optimization of pyrazole-based compounds with 1, 2, 4-triazole-3-thiol moiety as selective COX-2 inhibitors cardioprotective drug candidates: Design, synthesis, cyclooxygenase inhibition, anti-inflammatory, ulcerogenicity, cardiovascular evaluation, and molecular modeling studies. Bioorganic Chem. 2021, 114, 105122.

22. Haddad, N.N.; Bruns, B.R.; Enniss, T.M.; Turay, D.; Sakran, J.V.; Fathalizadeh, A.; Arnold, K.; Murry, J.S.; Carrick, M.M.; Hernandez, M.C. Perioperative use of nonsteroidal anti-inflammatory drugs and the risk of anastomotic failure in emergency general surgery. J. Trauma Acute Care Surg. 2017, 83, 657-661. [CrossRef]

23. Veronese, N.; Cooper, C.; Reginster, J.-Y.; Hochberg, M.; Branco, J.; Bruyère, O.; Chapurlat, R.; Al-Daghri, N.; Dennison, E.; Herrero-Beaumont, G. Type 2 diabetes mellitus and osteoarthritis. Proc. Semin. Arthritis Rheum. 2019, 49, 9-19. [CrossRef]

24. Tang, S.; Davoudi, Z.; Wang, G.; Xu, Z.; Rehman, T.; Prominski, A.; Tian, B.; Bratlie, K.M.; Peng, H.; Wang, Q. Soft materials as biological and artificial membranes. Chem. Soc. Rev. 2021, 50, 12679-12701. [CrossRef]

25. Shi, L.; Zhang, J.; Zhao, M.; Tang, S.; Cheng, X.; Zhang, W.; Li, W.; Liu, X.; Peng, H.; Wang, Q. Effects of polyethylene glycol on the surface of nanoparticles for targeted drug delivery. Nanoscale 2021, 13, 10748-10764. [CrossRef] [PubMed]

26. Davoudi, Z.; Peroutka-Bigus, N.; Bellaire, B.; Jergens, A.; Wannemuehler, M.; Wang, Q. Gut organoid as a new platform to study alginate and chitosan mediated PLGA nanoparticles for drug delivery. Mar. Drugs 2021, 19, 282. [CrossRef] [PubMed]

27. Prajapati, M.; Yamgar, D.B.; Desale, M.N.; Fegade, B. A Review on Various Analytical Methodologies for Etoricoxib. Adv. J. Grad. Res. 2022, 11, 61-70. [CrossRef]

28. Rehana, D.; Mahendiran, D.; Kumar, R.S.; Rahiman, A.K. Evaluation of antioxidant and anticancer activity of copper oxide nanoparticles synthesized using medicinally important plant extracts. Biomed. Pharmacother. 2017, 89, 1067-1077. [CrossRef]

29. Vaidehi, D.; Bhuvaneshwari, V.; Bharathi, D.; Sheetal, B.P. Antibacterial and photocatalytic activity of copper oxide nanoparticles synthesized using Solanum lycopersicum leaf extract. Mater. Res. Express 2018, 5, 085403. [CrossRef]

30. Gade, J.V.; Sharma, P.P.; Jain, B.; Rawat, R. Synthesis and characterization of paclitaxel nanoparticles for drug delivery. Mater. Today Proc. 2021, 51, 445-450. [CrossRef] 
31. Ahmad, M.Z.; Rizwanullah, M.; Ahmad, J.; Alasmary, M.Y.; Akhter, M.H.; Abdel-Wahab, B.A.; Warsi, M.H.; Haque, A. Progress in nanomedicine-based drug delivery in designing of chitosan nanoparticles for cancer therapy. Int. J. Polym. Mater. Polym. Biomater. 2021, 1-22. [CrossRef]

32. Esfahani, M.K.M.; Islam, N.; Cabot, P.J.; Izake, E.L. Development of Thiabendazole-Loaded Mesoporous Silica Nanoparticles for Cancer Therapy. ACS Biomater. Sci. Eng. 2021. [CrossRef] [PubMed]

33. Domper Arnal, M.-J.; Hijos-Mallada, G.; Lanas, A. Gastrointestinal and cardiovascular adverse events associated with NSAIDs. Expert Opin. Drug Saf. 2021, 1-12. [CrossRef]

34. Gurianov, Y.; Nakonechny, F.; Albo, Y.; Nisnevitch, M. LLDPE composites with nanosized copper and copper oxides for water disinfection. Polymers 2020, 12, 1713. [CrossRef]

35. Padmavathi, A.R.; Murthy, P.S.; Das, A.; Rao, T.S. Enhanced Antifouling Property of Polydimethylsiloxane-CuO nanocomposite in Marine Environment. Mater. Lett. 2021, 301, 130342. [CrossRef]

36. Shimabuku, Q.L.; Ueda-Nakamura, T.; Bergamasco, R.; Fagundes-Klen, M.R. Chick-Watson kinetics of virus inactivation with granular activated carbon modified with silver nanoparticles and/or copper oxide. Process. Saf. Environ. Prot. 2018, 117, 33-42. [CrossRef]

37. Menazea, A.; Ahmed, M. Synthesis and antibacterial activity of graphene oxide decorated by silver and copper oxide nanoparticles. J. Mol. Struct. 2020, 1218, 128536. [CrossRef]

38. El-Trass, A.; ElShamy, H.; El-Mehasseb, I.; El-Kemary, M. CuO nanoparticles: Synthesis, characterization, optical properties and interaction with amino acids. Appl. Surf. Sci. 2012, 258, 2997-3001. [CrossRef]

39. Khashan, K.; Jabir, M.; Abdulameer, F. Preparation and characterization of copper oxide nanoparticles decorated carbon nanoparticles using laser ablation in liquid. Proc. J. Phys. Conf. Ser. 2018, 1003, 12100. [CrossRef]

40. Singh, S.; Mishra, A.; Verma, A.; Ghosh, A.K.; Mishra, A.K. A simple Ultraviolet spectrophotometric method for the determination of etoricoxib in dosage formulations. J. Adv. Pharm. Technol. Res. 2012, 3, 237. [CrossRef]

41. Saravanan, M.; Reddy, P.P.; Naidu, M.; Babu, J.M.; Srivastava, A.K.; Kumar, T.L.; Sekhar, B.C.; Satyanarayana, B. Identification, synthesis, isolation and spectral characterization of potential impurities of montelukast sodium. J. Pharm. Biomed. Anal. 2008, 48, 708-715. [CrossRef] [PubMed]

42. Nakamoto, K. Infrared Spectra of Inorganic and Coordination Compounds; John Wiley and Son Inc.: New York, NY, USA; London, UK, 1963.

43. Padil, V.V.T.; Černík, M. Green synthesis of copper oxide nanoparticles using gum karaya as a biotemplate and their antibacterial application. Int. J. Nanomed. 2013, 8, 889.

44. Wahid, A.; Sridhar, B.; Shivakumar, S. Preparation and evaluation of transdermal drug delivery system of etoricoxib using modified chitosan. Indian J. Pharm. Sci. 2008, 70, 455.

45. Kesharwani, R.; Sachan, A.; Singh, S.; Patel, D. Formulation and evaluation of solid lipid nanoparticle (SLN) based topical gel of etoricoxib. J. Appl. Pharm. Sci. 2016, 6, 124-131. [CrossRef]

46. Patel, H.; Suhagia, B.; Shah, S.; Rathod, I.; Parmar, V. Preparation and characterization of etoricoxib- $\beta$-cyclodextrin complexes prepared by the kneading method. Acta Pharm. 2007, 57, 351-359. [CrossRef]

47. Das, A.; Nayak, A.K.; Mohanty, B.; Panda, S. Solubility and dissolution enhancement of etoricoxib by solid dispersion technique using sugar carriers. ISRN Pharm. 2011, 2011, 819765. [CrossRef]

48. Priyanka, K.; Hasan, S.A.A. Preparation and evaluation of montelukast sodium loaded solid lipid nanoparticles. J. Young Pharm. 2012, 4, 129-137. [CrossRef]

49. Naika, H.R.; Lingaraju, K.; Manjunath, K.; Kumar, D.; Nagaraju, G.; Suresh, D.; Nagabhushana, H. Green synthesis of CuO nanoparticles using Gloriosa superba L. extract and their antibacterial activity. J. Taibah Univ. Sci. 2015, 9, 7-12. [CrossRef]

50. Shi, L.-B.; Tang, P.-F.; Zhang, W.; Zhao, Y.-P.; Zhang, L.-C.; Zhang, H. Green synthesis of CuO nanoparticles using Cassia auriculata leaf extract and in vitro evaluation of their biocompatibility with rheumatoid arthritis macrophages (RAW 264.7). Trop. J. Pharm. Res. 2017, 16, 185-192. [CrossRef]

51. Senthilkumar, K.; Vijaya, C. Formulation development of mouth dissolving film of etoricoxib for pain management. Adv. Pharm. 2015, 2015, 702963. [CrossRef]

52. ZAVERI, M.; Khandhar, A. Development and Validation of a RP-HPLC for the Simultaneous estimation of Atenolol and Hydrochlorothiazide in Pharmaceutical Dosage Forms. Asian J. Pharm. Res. Health Care 2010, 2, 3.

53. Williams, L.; O'Connar, A.; Latore, L.; Dennis, O.; Ringer, S.; Whittaker, J.; Conrad, J.; Vogler, B.; Rosner, H.; Kraus, W. The in vitro anti-denaturation effects induced by natural products and non-steroidal compounds in heat treated (immunogenic) bovine serum albumin is proposed as a screening assay for the detection of anti-inflammatory compounds, without the use of animals, in the early stages of the drug discovery process. West Indian Med. J. 2008, 57, 327-331. [PubMed]

54. Kolhe, A.M.; Kale, A. Evaluation of analgesic, anti-inflammatory, and antipyretic activity of leukotriene receptor antagonistmontelukast: An experimental study. Natl. J. Physiol. Pharm. Pharmacol. 2017, 7, 32. [CrossRef]

55. Ullah, R.; Alsaid, M.S.; Alqahtani, A.S.; Shahat, A.A.; Naser, A.A.; Mahmood, H.M.; Ahamad, S.R.; Al-Mishari, A.A.; Ahmad, S. Anti-inflammatory, antipyretic, analgesic, and antioxidant activities of Haloxylon salicornicum aqueous fraction. Open Chem. 2019, 17, 1034-1042. [CrossRef] 
56. Abbah, J.; Amos, S.; Chindo, B.; Ngazal, I.; Vongtau, H.; Adzu, B.; Farida, T.; Odutola, A.; Wambebe, C.; Gamaniel, K. Pharmacological evidence favouring the use of Nauclea latifolia in malaria ethnopharmacy: Effects against nociception, inflammation, and pyrexia in rats and mice. J. Ethnopharmacol. 2010, 127, 85-90. [CrossRef] [PubMed]

57. Luna, I.Z.; Commission, B.A.E. Preparation and characterization of copper oxide nanoparticles synthesized via chemical precipitation method. Open Access Libr. J. 2015, 2, 1. [CrossRef]

58. Jat, R.; Chhipa, R.; Sharma, S. Spectrophotometric quantification of Etoricoxib in bulk drug and tablets using hydrotropic agent. Phramacore 2010, 1, 96-102.

59. Dalmora, S.L.; Brum Junior, L.; Ferretto, R.M.; Oliveira, P.R.d.; Barth, T.; Sangoi, M.d.S. Determination of etoricoxib in human plasma using automated on-line solid-phase extraction coupled with LC-APCI/MS/MS. Quimica Nova 2008, 31, 574-578. [CrossRef]

60. Mukai, Y.; Okamoto, R.; Takeuchi, S. Quantum fourier-transform infrared spectroscopy in the fingerprint region. arXiv 2021, arXiv:2110.14247.

61. Romanitan, C.; Mihalache, I.; Tutunaru, O.; Pachiu, C. Effect of the lattice mismatch on threading dislocations in heteroepitaxial GaN layers revealed by X-ray diffraction. J. Alloy. Compd. 2021, 858, 157723. [CrossRef]

62. Berkowicz, S.; Perakis, F. Exploring the validity of the Stokes-Einstein relation in supercooled water using nanomolecular probes Phys. Chem. Chem. Phys. 2021, 23, 25490-25499. [CrossRef] [PubMed]

63. Leelaprakash, G.; Dass, S.M. Invitro anti-inflammatory activity of methanol extract of Enicostemma axillare. Int. J. Drug Dev. Res. 2011, 3, 189-196.

64. Ratheesh, M.; Helen, A. Anti-inflammatory activity of Ruta graveolens Linn on carrageenan induced paw edema in wistar male rats. Afr. J. Biotechnol. 2007, 6, 10.

65. Moilanen, L.J.; Laavola, M.; Kukkonen, M.; Korhonen, R.; Leppänen, T.; Högestätt, E.D.; Zygmunt, P.M.; Nieminen, R.M.; Moilanen, E. TRPA1 contributes to the acute inflammatory response and mediates carrageenan-induced paw edema in the mouse. Sci. Rep. 2012, 2, 1-6. [CrossRef]

66. O'Callaghan, J.P.; Holtzman, S.G. Quantification of the analgesic activity of narcotic antagonists by a modified hot-plate procedure. J. Pharmacol. Exp. Ther. 1975, 192, 497-505. [PubMed]

67. Pathak, A.; Argal, A. Analgesic activity of Calotropis gigantea flower. Fitoterapia 2007, 78, 40-42. [CrossRef] [PubMed]

68. Makonnen, E.; Debella, A.; Zerihun, L.; Abebe, D.; Teka, F. Antipyretic properties of the aqueous and ethanol extracts of the leaves of Ocimum suave and Ocimum lamiifolium in mice. J. Ethnopharmacol. 2003, 88, 85-91. [CrossRef]

69. Pohocha, N.; Grampurohit, N.D. Antispasmodic activity of the fruits of Helicteres isora Linn. Phytother. Res. An. Int. J. Devoted Pharmacol. Toxicol. Eval. Nat. Prod. Deriv. 2001, 15, 49-52. 